\title{
Jonathan Wolff, An Introduction to Political Philosophy. Third Edition (Oxford: Oxford University Press, 2016), 231 p.
}

\author{
François Levrau
}

Als we de (westerse) politieke filosofie laten starten bij Plato, dan is deze tak van de filosofie zowat 2500 jaar oud. In die tijd zijn er heel wat vooraanstaande filosofen met heel wat uiteenlopende gedachten de revue gepasseerd. Wie het aandurft en aankan om al die denkers en al die reflecties in een boek van iets meer dan 200 bladzijden samen te brengen, die moet wel van goeden huize komen. Jonathan Wolff kan wat dat betreft alvast bogen op het voordeel van de twijfel. Op dit ogenblik is hij decaan van de Faculteit Letteren en Wijsbegeerte aan het prestigieuze University College London. De rode draad doorheen zijn academisch werk is sociale en distributieve rechtvaardigheid. Zo schreef hij onder meer een kritisch boek over Robert Nozick (wellicht de belangrijkste antagonist van John Rawls) en over Karl Marx, wiens theorie hij van blijvend belang acht om de hedendaagse samenleving kritisch te duiden. In 1998 schreef hij het niet geheel van invloed gespeende artikel 'Fairness, Respect and the Egalitarian Ethos' dat hij twaalf jaar later zelf becommentarieerde in een artikel dat hij dezelfde titel gaf. Wolff genoot zijn opleiding bij Gerald Allen Cohen die zich, ondanks zijn kritiek op Marx, altijd aan een aantal basisstellingen van het marxisme heeft gecommitteerd. Cohen is onder politiek filosofen niet alleen bekend omwille van zijn analytisch marxisme en zijn invloedrijke kritiek op Rawls, maar ook omwille van zijn humor. Wie denkt dat filosofie saai is, die moet op YouTube maar eens op zoek gaan naar het filmpje waarin Cohen in schier Monty Python-stijl de twee filosofische zwaargewichten John Roemer en Jürgen Habermas een intellectuele bokswedstrijd laat uitvechten. Filosofie rocks! De kunst om complexe gedachten op een bevattelijke wijze uit te leggen, heeft Wolff alvast van Cohen geërfd. Dat is wellicht ook de reden waarom hij een graag geziene gast is in de Britse media waar hem geregeld wordt gevraagd zijn licht te laten schijnen over een aantal filosofische kwesties. Wolff lijkt het soort vraagbaak te zijn dat je, zoals Mark Garnett op de achterflap van An Introduction to Political Philosophy aangeeft, graag aan je dineertafel zou willen hebben. Niet dat het antwoord op elk van je (levens)vragen zal worden gegeven, maar wijzer zal je in elk geval wel geworden zijn.

Laat mij het boek kort bespreken aan de hand van enkele aan elkaar gerelateerde vragen. Wat beoogt het boek eigenlijk en slaagt het daarin? Voor wie is het bestemd? Wat zijn de tekorten? Wat is de boodschap van het boek en zou ik het aan andere lezers aanbevelen?

Hoewel het boek een introductie in de politieke filosofie wil zijn, is het dat eigenlijk niet. In die zin is de titel wat misleidend. Zo heeft Wolff zich beperkt tot een 
zestal thema's die hij met behulp van een aantal kernauteurs bevattelijk maakt. In het voorwoord geeft hij zelf aan dat men het geredelijk met hem oneens kan zijn over de keuze van die thema's (en auteurs), maar tegelijk stelt hij dat zijn boek niet de pretentie heeft om een historisch overzicht te bieden van de vele kwesties waarover men zich in de politieke filosofie buigt, noch een poging wil zijn om een aantal kwesties op systematische wijze te doorgronden. Eerder dan dat gaat het erom dat de lezer een inkijk wordt gegeven in enkele van de problemen die in de politieke filosofie centraal staan en natuurlijk ook in enkele van de voornaamste antwoorden die op die problemen zijn geformuleerd. Dat maakt meteen ook dat sommige filosofen die tot de canon behoren slechts even in de marge worden vermeld en dat vele anderen gewoon niet aan bod komen. (Waar zijn bijvoorbeeld Immanuel Kant, Niccolò Machiavelli en Ronald Dworkin?) De thema's die Wolff in zijn boek aan de orde brengt, zijn: (1) de natuurstaat met daarbij een bespreking van Thomas Hobbes, John Locke, Jean-Jacques Rousseau en het anarchisme; (2) de rechtvaardiging van de staat met bijzondere aandacht voor het sociaalcontractdenken en het utilitarisme; (3) de vraag wie er moet regeren met daarbij een uiteenzetting van de opvattingen van Plato en Rousseau en met een toelichting van de representatieve democratie; (4) het belang van de liberale vrijheid met daarbij veel aandacht voor de inzichten van John Stuart Mill; (5) de herverdeling van bezit met aandacht voor de werking van de vrije markt en voor de theorieën van Rawls en Nozick; en tot slot (6) de scope van rechtvaardigheid met daarbij een aantal korte paragrafen over feminisme, affirmatieve actie, ras, personen met een handicap, seksuele geaardheid, conservatisme, globale rechtvaardigheid, immigratie en toekomstige generaties.

De politieke filosofie is dan misschien wel vijfentwintig eeuwen oud, ze is en blijft springlevend. De snelheid waarmee zich nieuwe thema's op de politiek filosofische agenda hebben geplaatst, heeft er Wolff alvast toe genoopt zijn boek een aantal keer te herzien. Zo verscheen de eerste versie in 1996 en werd het in 2006 en dus ook in 2016 gereviseerd. De herzieningen hebben voornamelijk betrekking op het zesde thema dat, zoals aangegeven, een aantal recente vraagstukken aan bod laat komen. Door de opname van die vraagstukken krijgt het boek een noodzakelijke update, maar door ze allemaal in één hoofdstuk op te nemen, mist de update wat scherpte. Het blijft knap hoe Wolff erin slaagt om telkens in een aantal pagina's tot de kern van die vraagstukken te komen, maar een wezenlijke herziening van het boek had erin bestaan dat hij, voor elk van de problematieken, een apart hoofdstuk had voorzien. Het is te begrijpen dat de auteur daarvoor niet heeft gekozen - want dan zou het niet langer om een herziening van een bestaand boek gaan, maar veeleer om een nieuw boek met meer nadruk op de 'hedendaagse politieke filosofie' - maar het had het boek wel sterker gemaakt.

Echt moeilijke passages zijn er in het boek niet te vinden - zoals aangegeven verstaat de auteur de kunst van het bevattelijk maken van complexe materie - waardoor ik vermoed dat een groot lezerspubliek ermee kan gebaat zijn: de docent die via het boek de klei krijgt aangeboden om er een aantal lessen mee te boetseren, de student die via de inzichten van Wolff over enkele handvatten beschikt om een 
aantal basisthema's en -auteurs beter te begrijpen en de geïnteresseerde leek die via de meeslepende stijl van Wolff kennis kan maken met wat de politieke filosofie te bieden heeft. Is dit dan ook voor de drie lezersgroepen het ideale boek? Dat valt te betwijfelen. De student is wellicht meer gebaat met bijvoorbeeld het filosofieboek van Catriona McKinnon omdat dit is opgevat als een syllabus met case studies, een verklarende woordenlijst, kaders die de essentie weergeven en gerichte vragen die de student kunnen helpen om de hoofdstukken in te studeren. De docent of de lezer die geavanceerde kennis wil verwerven, zal wellicht meer zijn gading vinden bij het filosofieboek van Will Kymlicka, al dient gezegd dat dit boek stilaan toe is aan een derde versie. Daarbij komt dat ook Kymlicka eigenlijk niet echt doet wat de titel van zijn boek Contemporary Political Philosophy: An Introduction doet vermoeden. Kymlicka biedt immers niet enkel een introducerend overzicht, tegelijk analyseert hij op grondige wijze en lijkt hij daardoor ook van tijd tot tijd positie in te nemen. Dat Kymlicka positie inneemt, is te begrijpen, want uiteindelijk is dat ook wat de politiek filosoof beroepshalve moet doen, namelijk aangeven hoe (bijvoorbeeld) de ideale samenleving er hoort uit te zien en waarom dat zo is. Daarmee is de professie van de politiek filosoof anders dan die van de politiek wetenschapper, gezien deze laatste veeleer beschrijft hoe de (politieke) samenleving er de facto uitziet. Wolff lijkt er in vergelijking met Kymlicka beter in te zijn geslaagd om zich afzijdig te houden. Misschien is dit ook waarom het bevoorrechte lezerspubliek van dit boek dan misschien toch de geïnteresseerde leek is. Wolff stelt enkel een aantal posities voor en geeft daarbij de sterkte- en zwaktepunten van die posities aan, maar hij verdedigt zelf nergens een bepaald (uitgewerkt) standpunt, wel integendeel, hij eindigt de meeste hoofdstukken met vragen en ergens op de laatste bladzijden stelt hij: 'Thus, while there can be more and less plausible positions and arguments, there can be no final word in political philosophy' (p. 215). Met die boodschap laat hij het finaal aan de lezer om verder aan de slag te gaan en/of om op zoek te gaan naar de elaboratie van die posities en argumenten.

Alles bij elkaar is Wolffs boek een 'brave' (er wordt geen positie verdedigd), 'intelligente' (de getoonde greep op de materie is krachtig), 'verantwoorde' (de selectie van thema's en auteurs is billijk) en 'leesbare' (alles wordt bevattelijk uitgelegd en met voorbeelden geduid) inleiding die het, als 'intellectuele injectie' verdient om door een ruim publiek gelezen te worden zodat onwetendheid en (al even erg) arrogantie enigszins kunnen worden tegengegaan. 